\title{
Lake water acidification and temperature have a lagged effect on the population dynamics of Isoëtes echinospora via offspring recruitment
}

Article

Accepted Version

Creative Commons: Attribution-Noncommercial-No Derivative Works 4.0

Čtvrtlíková, M., Hejzlar, J., Vrba, J., Kopáček, J., Nedoma, J., Hekera, P., Wade, A. and Roy, S. (2016) Lake water

acidification and temperature have a lagged effect on the population dynamics of Isoëtes echinospora via offspring recruitment. Ecological Indicators, 70. pp. 420-430. ISSN 1470-160X doi: https://doi.org/10.1016/j.ecolind.2016.06.042 Available at https://centaur.reading.ac.uk/65954/

It is advisable to refer to the publisher's version if you intend to cite from the work. See Guidance on citing.

To link to this article DOI: http://dx.doi.org/10.1016/j.ecolind.2016.06.042

Publisher: Elsevier

All outputs in CentAUR are protected by Intellectual Property Rights law, including copyright law. Copyright and IPR is retained by the creators or other copyright holders. Terms and conditions for use of this material are defined in the End User Agreement. 


\section{www.reading.ac.uk/centaur}

\section{CentAUR}

Central Archive at the University of Reading

Reading's research outputs online 
1 Lake water acidification and temperature have a lagged effect on the population

2 dynamics of Isoëtes echinospora via offspring recruitment

3

4

5 Martina Čtvrtlíkováa, Josef Hejzlar ${ }^{\mathrm{a}}$, Jaroslav Vrba ${ }^{\mathrm{a}, \mathrm{b}}$, Jiří Kopáček ${ }^{\mathrm{a}}$, Jiří Nedoma ${ }^{\mathrm{a}}$, Petr 6 Hekera $^{\mathrm{c}}$, Andrew J. Wade ${ }^{\mathrm{d}}$, Shovonlal Roy ${ }^{\mathrm{d}}$

7

$8{ }^{a}$ Biology Centre CAS, Institute of Hydrobiology, Na Sádkách 7, CZ-37005 České 9 Budějovice, Czech Republic

${ }^{b}$ University of South Bohemia, Faculty of Science, Branišovská 1760/31, CZ-37005 České

11 Budějovice, Czech Republic

c Palacký University Olomouc, Faculty of Science, 17. listopadu 1192/12, CZ-771 46 Olomouc, Czech Republic

${ }^{\mathrm{d}}$ University of Reading, Department of Geography and Environmental Science, Whiteknights, 15 RG6 6AB Reading, England

Author for correspondence: Martina Čtvrtlíková

Email: sidlatka@email.cz 


\section{Abstract}

The aquatic quillwort, Isoëtes echinospora, survived the strong water acidification during 1960s-1990s in Plešné Lake (Bohemian Forest, Central Europe), but failed to reproduce. We studied the relationships between a recent population recovery and an improvement of lake water quality. We used correlation analysis to evaluate lagged seasonal effects of lake water quality on population dynamics during the past decade, and factor analysis to determine the independent factors responsible for population recovery. We also provided a water-qualitybased reconstruction of population growth from the beginning of the lake recovery two decades ago, using a partial least squares regression (PLSR) model of population growth. We identified three independent controlling factors: nutrients (nitrate, phosphorus, calcium, potassium, magnesium), stressors ( $\mathrm{pH}$, ionic aluminium) and temperature. Of these, nutrient availability did not limit the quillwort growth, but annual mean $\mathrm{pH}$ and winter mean concentrations of toxic ionic aluminium influenced population growth through negative effects on sporeling establishment until the age of one year, while cumulative temperature in spring and summer controlled the later plant growth. Thus, water quality in the acidified Plešné Lake mainly controls recruitment success rather than adult survival of Isoëtes echinospora. This study provides the first in situ evidence that the recruitment success, namely the annual increment in the adult quillwort population, indicates the degree of recovery from acidification, however further extensive investigation is required to more accurately quantify, and therefore understand, the relationships between recruitment, water quality and other factors.

Key words: aluminium toxicity; aquatic plant; bioindication; herbivory; nutrients; plant lifehistory traits; population dynamics; reproductive ecology; stress 


\section{Introduction}

Isoetid species are small, slow-growing, evergreen water plants that are highly specialised for life in carbonate poor (weakly buffered) and nutrient poor (oligotrophic) lakes (Hutchinson 1975; Smolders, Lucassen \& Roelofs 2002). During the last century, isoetid vegetation in lakes of the Northern Hemisphere declined or became endangered due to anthropogenic acidification and eutrophication (Arts 2002; Brouwer, Bobbink \& Roelofs 2002; Smolders, Lucassen \& Roelofs 2002). Many of the atmospherically acidified lakes have been chemically and biologically recovering since the 1980s (e.g., Stoddard et al. 1999; Graham et al. 2007; Gray \& Arnott 2009; Garmo et al. 2014), allowing for unique ecological studies on the ecosystem functioning along rapidly changing temporal gradients of water chemistry. In contrast to fish, plankton and benthos, current knowledge on the environmental stress affecting isoetids in acidified lakes remains fragmented, since long-term quantitative data on their growth under in situ conditions has been missing. The successional changes in plant communities ascribed to lake water acidification are quite common in the literature (for review see Arts 2002), supported by inconsistently surveyed presence-absence data on 'sensitive' species. Only a few transplant (Brandrud \& Johansen 1994) or germination (Čtvrtlíková et al. 2009; Čtvrtlíková, Znachor \& Vrba 2014) experiments focused on the symptoms of plant sensitivity to particular stressors including low $\mathrm{pH}$ and toxic ionic aluminium $\left(\mathrm{Al}_{\mathrm{i}}\right)$. There is, however, no compelling evidence that these stressors within other physico-chemical conditions in situ play a significant role in decline of the original flora in acidified lakes (Arts 2002).

Isoetids obtain both nutrients and carbon from relatively rich sediments through a large root system (for review see Smolders, Lucassen \& Roelofs 2002), while the green aboveground parts of isoetid leaves are covered by thick cuticle, thus, only responsible for light absorbance and photosynthesis but not for nutrient uptake from lake water (Madsen, Olesen \& Bagger 2002). Isoetid vulnerability to changes in ambient water quality has been generally described in eutrophic lakes, where they are eventually outcompeted by taller rooting macrophytes, epiphytes, floating macrophytes, or phytoplankton (Arts 2002; Brouwer, Bobbink \& Roelofs 2002), all better competitors for nutrients dissolved in the water column and ultimately for light. By analogy, the shading effect of expanding acidotolerant macrophytes has also been suspected to be responsible for a large decline of isoetids in acidified lakes (Arts 2002; Brouwer, Bobbink \& Roelofs 2002). Since lake water acidification does not affect deeper sediment horizons (Herlihy \& Mills 1986; Kopáček et al. 2001), it remains unclear why the 
isoetids - with impermeable leaves and rooted in those favourable sediment horizons decline in acidified lakes, even if competitive plants are absent and light conditions are satisfactory for growth (Murphy 2002; Čtvrtlíková et al. 2009).

Quillworts (Isoëtes) are representatives of isoetid growth and typically are the dominant species in European unproductive lakes (Rørslett \& Brettum 1989; Murphy 2002). Sole, monospecific population of Isoëtes echinospora persists as a glacial relic in Plešné Lake (Bohemian Forest), which has been strongly acidified since the 1960s (Majer et al. 2003). Our laboratory experiments on the effects of strong acidity and $\mathrm{Al}_{\mathrm{i}}$ toxicity of lake water on spore germination of I. echinospora showed that both stressors significantly damaged the fine root system of the quillwort sporelings (Čtvrtlíková et al. 2009). Therefore, we hypothesised that the extreme stress during spring germination of I. echinospora has been responsible for the quillwort reproduction failure over the 30 years of severe acidification of Plešné Lake. Nontheless, there is no observed weakness in deeply rooted adult plants in the lake population. In fact, there were approximately 1000-5000 adult plants forming the population until the 2000s (Husák, Vöge \& Weilner 2000). The resistance of long living adults to lake water stressors most likely allowed for long-term survival of I. echinospora in acidified Plešné Lake. Recently we have witnessed remarkable reproduction recovery of the quillwort following improvement of the Plešné Lake water quality due to reduced sulphur and nitrogen deposition (Oulehle et al. 2013). In this study, we aim to elucidate the controlling role of the presumed environmental stressors that affect I. echinospora recruitment in Plešné Lake during its recovery from atmospheric acidification. To achieve this aim, the study has four objectives: (1) to assess relationships between population dynamics of I. echinospora and ambient lake water conditions in Plešné Lake, (2) to verify controlling roles of still seasonally high acidity and $\mathrm{Al}_{\mathrm{i}}$ toxicity in the quillwort renewal in situ, (3) to confirm that the early ontogenetic stages of I. echinospora are sensitive to environmental stresses associated with lake water acidification, and (4) to reconstruct the population growth from the beginning of the lake recovery two decades ago.

\section{Material and methods}

\subsection{Study site}

The population of I. echinospora Durieu has inhabited Plešné Lake situated in the Bohemian Forest, the Czech Republic ( $48^{\circ} 47^{\prime} \mathrm{N}, 13^{\circ} 52^{\prime} \mathrm{E}$; $1,087 \mathrm{~m}$ a.s.l.; Fig. 1) since the end of the last Glacial ( 10 kyr BP; Jankovská 2006). The lake is of glacial origin, dimictic, mesotrophic (area of 7.5 ha, volume of $617,000 \mathrm{~m}^{3}$, maximum depth of $18 \mathrm{~m}$ ), with small catchment area 
(66.6 ha) on granitic bedrock forested by Norway spruce (Picea abies) (Kopáček et al. 2007). The lake has been acidified by atmospheric deposition of sulphur (S) and nitrogen $(\mathrm{N})$ compounds since the late 1960s. Acidification progressed until the middle 1980s, when $\mathrm{pH}$ ranged between 4.4 and 4.7 , carbonate buffering system was entirely depleted, and total

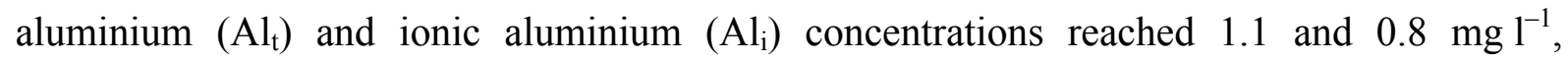
respectively (Kopáček et al. 2009). Since the 1990s, the lake chemistry has been recovering, with a temporary renewal of carbonate buffering capacity and increase of mean $\mathrm{pH}$ values to approximately 5 during summer stratification in the early 2000s. A partial lake water reacidification has occurred since 2004 due to forest dieback in the Plešné catchment due to bark-beetle infestation (Kaňa, Tahovská \& Kopáček 2013; Oulehle et al. 2013).

Isoëtes echinospora forms a monospecific plant stand in the inshore area of approximately 0.03 ha, at depths of $0.3-0.5 \mathrm{~m}$ (max. $1.0 \mathrm{~m}$; Čtvrtlíková et al. 2009). The lake shore is grown by Bottle Sedge (Carex rostrata); its dense stand forms a dynamic inshore border of the quillwort population. The sediment at the quillwort stand is an aqueous sapropel with a high proportion of organic matter. The lake is usually ice-covered from December to April.

\subsection{Population dynamics}

Population dynamics of $I$. echinospora in Plešné Lake were investigated at 3 adjacent study plots $(3 \times 10 \times 15 \mathrm{~m})$ covering most of the lake population $(95 \%$ in July 2013$)$. The plant stands outside the study plots were not taken into account as they had been gradually overgrown by the Bottle Sedge. Underwater visual censuses were performed in transitory strip transects $(0.5 \times 10 \mathrm{~m})$ using snorkelling every June-July from 2004 to 2014 and additionally in October 2013, when a plant stand disturbance occurred. All plant individuals in transects were recorded by the same observer throughout this study.

Two phenological stages of juvenile and adult plants were defined to determine the life history stages most sensitive to lagged environmental stresses (the quillwort phenology is illustrated in Fig. 2 according to Čtvrtlíková et al. 2012). A juvenile plant was a plant of more than four leaves and linear symmetry of the leaf rosette that survived the first winter. An adult plant was a plant with leaves (usually $>10$ ) clutched in a rosette of radial symmetry that survived more than two winter seasons. Sporelings, the (juvenile) plantlets established from germinating spores between May and June and forming less than four leaves until July (time of inspections), were not included in censuses of juvenile plants.

Plant abundance (number of individuals at the transects within three study plots), age structure (proportion of juvenile individuals), and population annual growth (year-to-year 
change of plant abundance) were evaluated from the census data to describe population dynamics. The abundance of adult plants before and after the plant stand disturbance in autumn 2013 was assessed in particular transect sections (not quadrates) grown by distinct plant assemblages and it was expressed per square meter and classified within intervals: 1; $10-100 ; 100-200$, and $>200$ individuals per $1 \mathrm{~m}^{2}$.

\subsection{Time lags}

Our previous findings showed that juvenile and adult population recruits from sporelings within one and two years, respectively (Čtvrtlíková et al. 2009; Fig. 2). Therefore, water quality effects on juvenile and adult population growth were tested with three and six time lags, respectively, which had been assumed to be biologically relevant. The time lags were related to the growing $(\mathrm{G})$, winter $(\mathrm{W})$ and spring $(\mathrm{S})$ periods up to two years before $(\mathrm{t}, \mathrm{t}-1, \mathrm{t}-$ 2 ) the current plant stage. The periods were defined by the water temperature threshold of $12^{\circ} \mathrm{C}$ for I. echinospora germination (Čtvrtlíková et al. 2012; Fig. 2). The growing and winter periods distinguished between the daily mean temperature above and below $12^{\circ} \mathrm{C}$, respectively. The spring period began when the water temperature first time surpassed the $12^{\circ} \mathrm{C}$ threshold and included both the next 60 days when daily mean temperature was $>12^{\circ} \mathrm{C}$ (according to Čtvrtlíková et al. 2012) and any intermittent day when the temperature was < $12^{\circ} \mathrm{C}$ (if present). We suppose that the offspring recruited to the adult population (i.e. censused 'new' adults) during current spring $\left(\mathrm{S}_{\mathrm{t}}\right)$ had been at its juvenile age within the last winter $\left(\mathrm{W}_{\mathrm{t}-1}\right)$, the last growing $\left(\mathrm{G}_{\mathrm{t}-1}\right)$ period and the last spring $\left(\mathrm{S}_{\mathrm{t}-1}\right)$, and at its sporeling age within the first winter $\left(\mathrm{W}_{\mathrm{t}-1}\right)$ and the first growing period $\left(\mathrm{G}_{\mathrm{t}-2}\right)$, when born (Fig. 2). The sporelings recruited to the juvenile population (i.e. censused juveniles) during current spring $\left(\mathrm{S}_{\mathrm{t}}\right)$ overwintered only once, during the last winter $\left(\mathrm{W}_{\mathrm{t}-1}\right)$, since they had originated during the last growing $\left(\mathrm{G}_{\mathrm{t}-1}\right)$ period (Fig. 2).

\subsection{Environmental conditions}

Lake water temperature $\left({ }^{\circ} \mathrm{C}\right)$ and photosynthetically active radiation (PAR, $\mu \mathrm{mol} \mathrm{m} \mathrm{s}^{-1}$ ) in the quillwort plant stand was recorded with the Minikin QT smart sensor (Environmental Measuring Systems Company, Brno, Czech Republic) in 30-minute intervals from June 2003 to July 2014 (parallel to the plant observation period). Temperature and PAR effects on the quillwort growth were analysed from these measured data. Lake water temperature data for hindcast modelling of quillworts growth in 1997-2003 were reconstructed by a mathematical temperature lake model (CE-QUAL-W2; Cole \& Wells 2015), calibrated on the 2004-2013 period with climatic data from a nearby meteorological station of the Czech 
Hydrometeorological Institute (Churáňov; 4904'N,1337'E; 1118 m a.s.1.). The agreement of daily means from the measured and simulated water temperature data was good (mean error, $0.0^{\circ} \mathrm{C}$; mean absolute error, $0.8^{\circ} \mathrm{C}$; root mean square error, $1.1^{\circ} \mathrm{C} ; \mathrm{R}^{2}, 0.98$ ). Aquatic quillworts are well adapted to grow at low ambient light (e.g. Keeley 1998) and light conditions in the shallow stands of I. echinospora in Plešné Lake might comply with the species preferences (Gacia \& Ballesteros 1994) during the past decades, when water level was stable (with maximum oscillations $\pm 10 \mathrm{~cm}$ during high flow events or rare occasions of dry and hot weather) and water transparency satisfactory ( $>1.5 \mathrm{~m}$ in summer; Vrba et al. 2000). Daily mean water temperature was used to identify the spring, growing and winter periods in 1998-2013. To study the temperature effect on population dynamics, we used the following characteristics: (i) seasonal mean temperature (average of daily mean temperature, $\mathrm{T}_{\mathrm{m}}$ ), (ii) cumulative temperature (sum of daily mean temperature, $T_{c}$ ), (iii) cumulative days (sum of days within a period, $\mathrm{D}_{\mathrm{c}}$ ), and (iv) temperature variation during a period (standard deviation, $T_{v}$ ) that were calculated for the spring, growing and winter periods. To study the effects of lake water chemistry on population dynamics, mean values of $\mathrm{pH}, \mathrm{NO}_{3}-\mathrm{N}$, total phosphorus (TP), $\mathrm{Ca}, \mathrm{K}, \mathrm{Mg}, \mathrm{Al}_{\mathrm{t}}$, and $\mathrm{Al}_{\mathrm{i}}$ concentrations in an epilimnetic outflow of Plešné Lake were calculated for the respective periods. These characteristic were selected from a wider range of long-term data on water chemistry with respect to the nutrients preferred by quillworts (Smolders, Lucassen \& Roelofs 2002) and the species-specific adverse effects of acidity and $\mathrm{Al}_{\mathrm{i}}$ toxicity (Čtvrtlíková et al. 2009). Lake water was sampled from the depth of 0.05-0.3 $\mathrm{m}$ at the outflow of Plešné Lake several times (1-8 samplings) a year in summer-to-autumn period between 1990 and 1997 and in 1- to 3-week intervals between 1998 and 2014. TP was determined by perchloric acid digestion and the molybdate method according to Kopáček \& Hejzlar (1993). Concentrations of $\mathrm{NO}_{3}-\mathrm{N}$ and other ions $\left(\mathrm{Ca}^{2+}, \mathrm{Mg}^{2+}, \mathrm{K}^{+}\right)$were determined by ion chromatography (Dionex IC25, USA). $\mathrm{Al}_{\mathrm{t}}$ and $\mathrm{Al}_{\mathrm{i}}$ were analysed according to Driscoll (1984) using the spectrophotometric method by Dougan \&Wilson (1974) and $\mathrm{pH}$ was measured using a glass electrode (Radiometer PHC2401).

\subsection{Statistical analyses}

The Pearson correlation analysis was performed to identify candidates for both response and predictor variables explaining the quillwort population recovery which was visually observed between 2004 and 2013. The response $(Y)$ variables in the analysis included plant abundance and population growth, each specified for juvenile and adult stage. The predictor variables $(X)$ included the 12 above mentioned physicochemical lake water characteristics, each lagged by 
age at different periods. The best scores of correlation coefficients for explanatory response and predictor variables were assessed, using the software package STATISTICA 12 (product/module STATISTICA Base; StatSoft, Inc., Tulsa, OK, USA).

The factor analysis was performed to help to find an explanation for the quillwort recovery, in particular to identify a reduced number of independent factors from the correlated observed predictors influencing the population growth. Factor analysis was applied to the most important time lag at which eight of the lake water characteristics, including lake water chemistry and temperature, operated. The meanings and the true explanatory magnitudes of latent factors were evaluated from the factor loadings of the rotated matrix Varimax, the variability explained by each factor $\left(\mathrm{R}^{2}\right)$, and the communalities for each variable, using the software package STATISTICA12 (product STATISTICA advanced, module STATISTICA Multivariate Exploratory Techniques).

The partial least squares regression (PLSR) model was used for a water-quality-based reconstruction of population growth in 1998-2003. Data on the adult population growth (response variable, $Y$; 2005-2013) and the same (eight) lake water characteristics (predictor variables, $X_{i}$; 1998-2013) re-inserted from the factor analysis were used in PLSR, designed as a multiple linear regression model. The meaning and the true explanatory magnitude of latent components was estimated from the weights of the original predictor variables and the total explanatory capacity ( $\mathrm{R}^{2}$ of $Y$ and $\mathrm{R}^{2}$ of $X_{i}$ ) of extracted components. The following regression equation was used to explore the growth reconstruction:

$Y=b_{0}+\sum_{i}^{8} b_{i} X_{i}$

where $b_{0}$ is the regression coefficient for the intercept and the $b_{\mathrm{i}}$ values are the regression coefficients (for the predictor variables 1 through 8 ) computed from the data. The abundance reconstruction was also provided using data on modelled growth (referring to inter-annual difference in abundance). The regression algorithm was performed by the Statistica 12 (product STATISTICA advanced, module STATISTICA Advanced Linear/Nonlinear Models). No model was used for predicting the quillwort improvement in the ongoing decade as the population was largely reduced at the end of our study (in 2013).

\section{Results}

Environmental conditions

Long-term monitoring of water chemistry in Plešné Lake (Fig. 3) demonstrated a steady decrease in sulphate since 1990 in response to the reduced nitrogen and sulphur deposition. 
Summer values of $\mathrm{pH}$ increased above 5 and the seasonal re-establishment of carbonate buffering system has occurred in the epilimnion since 1999 (Fig. 3a). In parallel, the seasonal summer-to-autumn minima of $\mathrm{Al}_{\mathrm{i}}$ concentration decreased to $<0.1 \mathrm{mg} \mathrm{l^{-1 }}$, although its spring peaks remained high (up to $0.4 \mathrm{mg} \mathrm{l}^{-1}$; Fig. 3b). Nitrate concentrations increased markedly after the large-scale forest dieback in the Plešné catchment during 2006-2009 and peaked two years later (Fig. 3d) due to elevated terrestrial export, resulting from increased mineralization of fresh litter and ceased uptake after the forest dieback (Kaňa, Tahovská \& Kopáček 2013). The elevated leaching of nitrate was compensated for by increased leaching of cations, especially $\mathrm{Al}_{\mathrm{i}}, \mathrm{K}, \mathrm{H}, \mathrm{Ca}$ and $\mathrm{Mg}$ (Fig. 3a-c). The forest dieback also resulted in elevated $\mathrm{TP}$ leaching (Fig. 3a).

\section{Population dynamics}

Plant abundance of I. echinospora in Plešné Lake observed in 2004 (Fig. 4a) was similar to that reported before 1998 (Husák, Vöge \& Weilner 2000). A recovery of the quillwort population was observed between 2006 and 2013, when the total plant abundance increased steadily, showing a proportion of more than $20 \%$ of juvenile plants every year (Fig. $4 \mathrm{a}$ ). Population growth (Fig. 4b) reflected recruitment success rather than adult survival, since low mortality of adults has been observed in situ.

\section{Pearson correlation analysis}

Population growth in general and adult growth in particular showed significant $(p<0.05)$ correlations with lake water $\mathrm{pH}, \mathrm{Al}_{\mathrm{i}}$, and temperature (Table 1, Fig. 2, 5). Seasonally high water acidity (low $\mathrm{pH}$ ) and $\mathrm{Al}_{\mathrm{i}}$ concentrations affected adult growth through negative (toxic) effects on establishment of early ontogenetic stages. The only time lag at which $\mathrm{Al}_{\mathrm{i}}$ operated was age at the first wintering $\left(\mathrm{W}_{\mathrm{t}-1}\right.$; Table 1, Fig. 2), whereas responsiveness to $\mathrm{pH}$ was determined also at two subsequent time lags corresponding to a plantlet age $\leq 1$ year (between $\mathrm{W}_{\mathrm{t}-1}$ and $\mathrm{G}_{\mathrm{t}-1}$; Table 1, Fig. 2). Clear signs of the positive relationships between adult growth and spring-to-summer temperature $\left(\mathrm{T}_{c}, \mathrm{~T}_{\mathrm{var}}\right.$, or $\left.\mathrm{D}_{\mathrm{c}}\right)$ were determined at the time lags corresponding to age $\geq 1$ year $\left(\mathrm{G}_{\mathrm{t}-1}\right.$ and $\mathrm{S}_{\mathrm{t}}$; Table 1, Fig. 2). In addition, significant $(p<0.05)$ positive relationship between adult growth and total phosphorus (TP) lagged at the last $\left(\mathrm{S}_{\mathrm{t}-1}\right)$ and current $\left(\mathrm{S}_{\mathrm{t}}\right)$ spring was shown (Table 1, Fig. 2).

Cumulative rather than mean thermal characteristics have profound effects on the population dynamics (Table 1, Fig. 5). The cumulative water temperature available for the I. echinospora growth in Plešné Lake in the spring and growing periods was $924-1361^{\circ} \mathrm{C}$ (average of $1086 \pm$ $\left.111^{\circ} \mathrm{C}\right)$ and $1693-2474^{\circ} \mathrm{C}\left(2121 \pm 220^{\circ} \mathrm{C}\right)$, respectively, during the past 15 years. The spring and growing periods began in May and lasted 60-80 days (67 \pm 6 days) and 98-151 days (127 
\pm 15 days), respectively. Water temperature was significantly controlled by atmospheric PAR (Pearson $r>0.85, p<0.05$; data not shown) showing analogous effects on adult growth.

Therefore, atmospheric radiation was excluded from further analyses and only temperature was used, representing the underwater thermal conditions.

Factor analysis

Three independent factors explained $98 \%$ of the total variability of eight lake water characteristics lagged by age at the first wintering $\left(\mathrm{W}_{\mathrm{t}-1}\right)$, which are clearly separated into four clusters using Factor Analysis (Table 2, Fig. 6). The first factor is marked by high nutrient concentrations including $\mathrm{NO}_{3}-\mathrm{N}, \mathrm{TP}, \mathrm{Ca}, \mathrm{K}$, and $\mathrm{Mg}$, which all are correlated with each other. The second factor is marked by the biotoxic stressors accompanied with the lake water acidification, including negatively intercorrelated $\mathrm{pH}$ and $\mathrm{Al}_{\mathrm{i}}$ (two opposite clusters). The third factor is marked by water temperature, represented by $\mathrm{T}_{\mathrm{c}}$.

\section{Partial least squares regression model}

The results of the Partial least squares regression analysis demonstrated that three components explain $85 \%$ of the original variance in the adult growth (Table 2, Fig. 7a). The first component accounts for a major proportion (58\%) of the explained variance and associates negatively correlated $\mathrm{pH}$ and $\mathrm{Al}_{\mathrm{i}}$. The second and the third component account for almost the same proportion $(14 \%$ and $13 \%)$ of the explained variance and are dominated by $\mathrm{Al}_{\mathrm{i}}$ associated to temperature and $\mathrm{pH}$ (positive correlation between $\mathrm{Al}_{\mathrm{i}}$ and $\mathrm{pH}$ ), respectively. The 2- and 3-component PLSR models rather than the 1-component model fit the data for the whole period 2005-2013, as well as for the extreme events in 2006 (high growth in situ) and 2011 (low growth in situ). The two higher-component models, however, diverge substantially, when extrapolating beyond the observation period in 2000 and 2003. Nevertheless, the results from all the three models show that recovery of $I$. echinospora in Plešné Lake is predominantly controlled by the reduction in winter $\mathrm{Al}_{\mathrm{i}}$ concentrations and acidity of the lake water. It is evident that intermittent mitigations of both stressors have enabled a discontinuous growth of the population since 2001. From the three growth models, relevant adult plant abundances were reconstructed, explaining each of about $90 \%$ of variance in the observed abundances between 2004 and 2013 (Fig. 7b). Nonetheless, only the abundance provided from the 2-component model shows the most realistic feature, as it fits well the former field observations (Husák, Vöge \& Weilner 2000), when extrapolated between 1999 and 2004.

\section{Plant disturbance}

Highly dense stands of the quillwort population formed during recovery from acidification (Fig. 8) were suddenly grazed by Mallards (Anas platyrhynchos), which damaged $90 \%$ of all 
plants in the population within a month between August and October 2013. The field observations showed a consumptive grazing of a female with seven grown ducklings on stunted stems of adult plants. Because some of the damaged plants regenerated, the abundance of adult and juvenile plants in summer 2014 was reduced by $73 \%$ and $83 \%$, respectively, when compared with that in July 2013 (Fig. 8). The proportion of juveniles in 2014 was in line with the recovery trend prior to the population disturbance (Fig. 4a).

\section{Discussion}

This study brings compelling evidence that water quality controls I. echinospora recruitment in the acidified Plešné Lake. Low $\mathrm{pH}$ and high $\mathrm{Al}_{\mathrm{i}}$ concentrations, both known as rootinhibitors, are clearly distinguished from the other lake water compounds as synergistic acidification stressors that prevent development of the early ontogenetic stages of the quillwort (Tables 1 and 2, Fig. 5, 6). The sporelings and juveniles with short roots developing at the sediment surface are affected by the acidic lake water, but it is not detrimental to the deep rooted adults. Survival of the population, which lost sporelings due to the harsh conditions, depends entirely on the adult perennials, since quillworts cannot reproduce clonally. There is missing information, whether the plantlets establishing on ramets of the other isoetids that are capable of clonal reproduction would be also affected by lake water acidity or they would benefit from a physiological integrity. A renewal failure due to lake water pollution and gradual senescence of an isoetid plant stand may result in a decline in population size, even if the adults grow under satisfactory conditions.

In Plešné Lake recovering from acidification, I. echinospora recruitment has still been inhibited by the seasonal or episodic extremes in acidity and elevated $\mathrm{Al}_{\mathrm{i}}$ concentrations, caused by snow melting or high precipitation events (Fig. 3a, b, 5). We identified the early ontogenetic stages of the quillwort until the age of $\sim 1$ year to be sensitive to these environmental stresses, when surpassing certain thresholds (Table 1, Fig. 2, 5). The thresholds of $\mathrm{Al}_{\mathrm{i}}\left(0.3 \mathrm{mg}^{-1}\right)$ and $\mathrm{pH}$ (5.0) for sporeling establishment of $I$. echinospora derived from laboratory experiments (Čtvrtlíková et al. 2009) are clearly effective under the lake conditions as well (Fig. 5). The $\mathrm{Al}_{\mathrm{i}}$ concentrations have still exceeded the threshold in winter, but they could prevent any sporeling recruitment only in synergy with the extreme acidity $(\mathrm{pH}<4.9$; Fig. 5). In addition, the juveniles may be further impaired by the extreme acidity itself during spring and/or summer, when Al-toxicity is not critical (periods $\mathrm{S}_{\mathrm{t}-1}$ and $\mathrm{G}_{\mathrm{t}-1}$; Table 1). Interestingly, no stress from any of the lake water condition was observed within the very first few months of a sporeling life (period $\mathrm{G}_{\mathrm{t}-2}$, Table 1), when the plantlet is still attached to macrogametophyte storage tissue (Eames 1936; Foster \& Gifford 1959), and a supplemental 
nutrition may temporarily offset the nutrient deficiency caused by a dysfunction of sporeling roots under the harsh conditions.

Population growth of I. echinospora in Plešné Lake was most likely absent over 30 years between 1970 and 2000 due to all-year-long extreme acidity and high $\mathrm{Al}_{\mathrm{i}}$ concentrations in the lake water (Majer et al. 2003; Fig. 3a, b) exceeding the thresholds for the offspring survival. Our reconstruction model (Table 2, Fig. 7a, b) supports the presence of numerous adult survivors during that time reported by Husák, Vöge \& Weilner (2000). Such a long survival despite the severe chemical conditions indicates the high resistance of adult plants to the stressors in lake water, as well as the long life span of I. echinospora. The model further showed the discontinuous population recovery during the past 15 years (Fig. 7b), when relatively favourable conditions in growing period (Fig. 3, 5) allowed for spore germination and sporeling development, as well as for regeneration of grown juveniles after being exposed to the still occasionally harmful conditions in winter.

An annual increment in the adult quillwort population is the most important life-history parameter for reliable estimates of stress responsiveness lagged by age at early ontogeny (Table 1). Alternatively, abundance or annual growth of the juvenile population is a poor indicator for stress tolerance during a plant life history (Table 1). Neither adults nor juveniles of I. echinospora were influenced by water column nutrient concentrations (Table 1, Fig. 5), what is in conformity with the known fact that nutrient availability does not limit the growth of quillworts adapted to oligotrophic conditions (Smolders, Lucassen \& Roelofs 2002). The only significant positive correlation between the juvenile stage and total phosphorus in spring $\left(\mathrm{S}_{\mathrm{t}-1}\right.$; Table 1) is likely an artefact caused by the increasing trend in TP.

The I. echinospora plantlets of the age of $\sim 1$ year are no more influenced by the acidification stressors, but their growth is controlled by lake water temperature in Plešné Lake (Table 1, Fig. 2 and 5). The change in environmental drivers during the second summer of a plantlet life probably indicates that its root system reaches relatively deep sediment, where the acidic A1 rich lake water does not penetrate. At that time, only the heat transmitted from aboveground starts to control the intrinsic slow growth of the quillwort, so that the prolonged spring with altering warm and cold spells has a clear positive effect of on the establishment of adult plants (Table 1). Our analyses showed that the minimum water temperature threshold of $12^{\circ} \mathrm{C}$ for $I$. echinospora germination derived from laboratory experiments by Čtvrtlíková et al. (2012) fits well for the growth of the lake plants too. The cumulative thermal characteristics $\left(T_{c}\right.$ and $\left.D_{c}\right)$ rather than mean temperature are suitable for assessing a thermal response of the quillwort (Table 1) and may provide useful predictors of the quillwort phenophases and distribution in 
analogy to widely used effective temperature sums (e.g., McMaster \& Wilhelm 1997), growing degree-days (e.g., Lindgren \& Walker 2012), or season length.

To our best knowledge, this is the first long term ( $>14$ years) study of an isoetid population dynamics based on intensive repeated measurements in situ. We observed strongly reductive effects of an anthropogenic as well as natural disturbance on the glacial relic population of $I$. echinospora in Plešné Lake. In addition to acidification effects, we bring (accidental but unique) details on mallards grazing on aquatic quillwort I. echinospora (Fig. 8). Grazing by Mallards (Anas platyrhynchos), Canada Geese (Branta canadensis), or Common Loon (Gavia immer) have been briefly noted for several quillwort species including I. echinospora (Brunton \& Britton 1999). The Mallards grazing preference of dense plant stands might be the reason why the quillwort population in Plešné Lake was untouched during its recovery until reaching the high density in 2013 (Fig. 8). The leaves clipped (uneaten) from the damaged plants in autumn were observed to spread along the entire shoreline, where maturing spores might be released from their sporangia; yet no sporelings have been observed there since the next spring. This indicates a large loss of individuals reducing a genetic variability of the population, which already might be low due to its decline during acidification period, or some other disturbances in the shallow littoral. Given the responsiveness of I. echinospora recruitment to the recent trends in chemistry of Plešné Lake (Majer et al. 2003), the current growth rate of the resting population is anticipated to continue or even increase.

\subsection{Conclusions}

As hypothesized, lake water quality controls Isoëtes echinospora recruitment in Plešné Lake recovering from acid stress. In particular, seasonal extremes in acidity and aluminium-toxicity have lagged effects on population dynamics, allowing for water-quality-based reconstruction of population growth since the beginning of lake recovery two decades ago. Our study revealed an important life-history parameter for reliable estimates of stress responsiveness of Isoëtes echinospora lagged by age at its early ontogeny. Isoëtes echinospora is an iconic macrophyte of oligotrophic softwater lakes that have been suffering from environmental degradation. This study brings compelling evidence that the quillwort possesses an indicatory capacity for determining the status of recovering lake ecosystems.

\section{Acknowledgements}

Funding: This work was supported by the European Social Fund and the State budget of the Czech Republic [grant number CZ.1.07/2.3.00/30.0032]; the Czech Science Foundation [grant 
numbers 206/07/1200, P504/12/1218]; and the Institute of Botany CAS, v.v.i. [grant number AV0Z60050516]. We thank Jiří Jarošík and Jan Turek for technical support with modelling of temperature and light conditions in Plešné Lake.

\section{References}

Arts, G.H.P., 2002. Deterioration of Atlantic soft water macrophyte communities by acidification, eutrophication, and alkalinisation. Aquat. Bot. 73, 373-393.

Brandrud, T.E., Johansen, S.W., 1994. Effects of acidification on macrophyte growth in the humex lake Skjervatjern, with special emphasis on Sphagnum auriculatum. Environ. Int. 20, $329-342$.

Brouwer, E., Bobbink, R., Roelofs, J.G.M., 2002. Restoration of aquatic macrophyte vegetation in acidified and eutrophied softwater lakes: an overview. Aquat. Bot. 73, 405-431.

Brunton, D.F., Britton, D.M., 1999. Maritime quillwort, Isoëtes maritime (Isoëtaceae), in the Yukon Territory. Can. Field-Naturalist. 113 (4), 641-645.

Cole, T.M., Wells, S.A., 2015. CE-QUAL-W2: A Two-Dimensional, Laterally Averaged, Hydrodynamic and Water Quality Model, Version 3.72. User Manual. Department of Civil and Environmental Engineering, Portland State University, USA, Portland.

Čtvrtlíková, M., Znachor, P., Vrba, J., 2014. The effect of temperature on the phenology of germination of Isoëtes lacustris. Preslia. 86, 279-292.

Čtvrtlíková, M., Znachor, P., Nedoma, J., Vrba, J., 2012. Effects of temperature on the phenology of germination of Isoëtes echinospora. Preslia. 84, 141-153.

Čtvrtlíková, M., Vrba, J., Znachor, P., Hekera, P., 2009. The effects of aluminium toxicity and low pH on the early development of Isoëtes echinospora. Preslia. 81, 135-149.

Dougan, W.K., \& Wilson, A.L., 1974. The absorptiometric determination of aluminium in water. A comparison of some chromogenic reagents and the development of an improved method. Analyst. 99, 413-430.

Driscoll, C.T., 1984. A procedure for the fractionation of aqueous aluminum in dilute acidic waters. Int. J. Environ. Analytical Chem. 16, 267-284. 
Eames, A.J., 1936. Morphology of vascular plants. Lower groups (Psilophytales to Filicales), McGraw-Hill Book Company, New York.

Foster, S., Gifford, E.M., 1959. Comparative Morphology of Vascular Plants, W. H. Freeman and Company, San Francisco.

Garmo, O.A., Skjelkvale, B.L., de Wit, H.A., Colombo, L., Curtis, C., Folster, J., Hoffmann, A., Hruška, J., Høgåsen, T., Jeffries, D.S., Keller, W.B., Krám, P., Majer, V., Monteith, D.T., Paterson, A.M., Rogora, M., Rzychon, D., Steingruber, S., Stoddard, J.L., Vuorenmaa, J. \& Worsztynowicz, A., 2014. Trends in surface water chemistry in acidified areas in Europe and North America from 1990 to 2008. Water, Air, \& Soil Pollut. 225: 1880.

Graham, M.D., Vinebrooke, R.D., Keller, B., Heneberry, J., Nicholls, K.H., Findlay, D.L., 2007. Comparative responses of phytoplankton during chemical recovery in atmospherically and experimentally acidified lakes. J. Phycol. 43, 908-923.

Gray, D.K., Arnott, S.E., 2009. Recovery of acid damaged zooplankton communities: measurement, extent, and limiting factors. Environ. Rev. 17, 81-99.

Herlihy, A.T., Mills, A.L., 1986. The $\mathrm{pH}$ regime of sediments underlying acidified waters. Biogeochem. 2, 95-99.

Husák, Š., Vöge, M., Weilner, C., 2000. Isoëtes echinospora and I. lacustris in the Bohemian Forest lakes in comparison with other European sites. Silva Gabreta. 4, 245-252.

Hutchinson, G.E., 1975. A Treatise on Limnology: Limnological Botany, Wiley, New York. Jankovská, V., 2006. Late Glacial and Holocene history of Plešné Lake and its surrounding landscape based on pollen and palaeoalgological analyses. Biologia. 61, 371-385.

Kaňa, J., Tahovská, K., Kopáček, J., 2013. Response of soil chemistry to forest dieback after bark beetle infestation. Biogeochem. 113 (1-3), 369-383.

Kopáček, J., Hejzlar, J., 1993. Semi-micro determination of total phosphorus in fresh waters with perchloric acid digestion. Int. J. Environ. Analytical Chem. 53, 173-183.

Kopáček, J., Hejzlar, J., Kaňa, J., Norton, S.A., Porcal, P., Turek, J., 2009. Trends in aluminium export from a mountainous area to surface waters, from deglaciation to the recent: 
Effects of vegetation and soil development, atmospheric acidification, and nitrogensaturation. J. Inorg. Biochem. 103, 1439-1448.

Kopáček, J., Marešová, M., Hejzlar, J., Norton, S.A., 2007. Natural inactivation of phosphorus by aluminium in preindustrial lake sediments. Limnology and Oceanogr. 52 (3), $1147-1155$.

Kopáček, J., Ulrich, K.U., Hejzlar, J., Borovec, J., Stuchlík, E., 2001. Natural inactivation of phosphorus by aluminium in atmospherically acidified water bodies. Water Res. 35, 37833790.

Lindgren, C.J., Walker, D., 2012. Growth Rate, Seed Production, and Assessing the Spatial Risk of Lythrum salicaria using Growing Degree-Days. Wetlands. 32, 885-893.

Madsen, T.V., Olesen, B., Bagger, J., 2002. Carbon acquisition and carbon dynamics by aquatic isoetids. Aquat. Bot. 73, 351-371.

Majer, V., Cosby, B.J., Kopáček, J., Veselý, J., 2003. Modelling reversibility of Central European mountain lakes from acidification: Part I - the Bohemian Forest. Hydrol. and Earth System sciences. 7, 494-509.

McMaster, G.S., Wilhelm, W.W., 1997. Growing degree-days: one equation, two interpretations. Agric. and Forest Meteorol. 87(4), 291-300.

Murphy, K.J., 2002. Plant communities and plant diversity in softwater lakes of northern Europe. Aquat. Bot. 73, 287-324.

Oulehle, F., Chuman, T., Majer, V., Hruška, J., 2013. Chemical recovery of acidified Bohemian lakes between 1984 and 2012: the role of acid deposition and bark beetle induced forest disturbance. Biogeochem. 116 (1-3), 83-101.

Rørslett, B., Brettum, P., 1989. The genus Isoëtes in Scandinavia: an ecological review and perspectives. Aquat. Bot. 35, 223-261.

Smolders, A.J.P., Lucassen, E.C.H.E.T., Roelofs, J.G.M., 2002. The isoetid environment: biochemistry and threats. Aquat. Bot. 73, 325-350.

Stoddard, J.L., Jeffries, D.S., Lükewille, A., Clair, T.A., Dillon, P.J., Driscoll, C.T., Forsius, M., Johannessen, M., Kahl, J.S., Kellogg, J.H., Kemp, A., Mannio, J., Monteith, D., Murdoch, 
P.S., Patrick, S., Rebsdorf, A., Skjelkvåle, B.L., Stainton, M.P., Traaen, T., van Dam, H., Webster, K.E., Wieting J., Wilander, A., 1999. Regional trends in aquatic recovery from acidification in North America and Europe. Nat. 401, 575-578.

Table 1 Pearson correlation coefficients $(r)$ between population growth $(Y)$ of Isoëtes echinospora in Plešné Lake and the lake water characteristics $(X)$ lagged at spring (S), growing $(\mathrm{G})$ or winter (W) periods up to two years backward $(\mathrm{t}, \mathrm{t}-1, \mathrm{t}-2)$; for the period settings and the respective phenophases see methods and Fig. 2. The growth $(Y)$ is defined as a year-to-year change in number of adult or juvenile plants observed in July. The lake water characteristics are $\mathrm{pH}$, nitrate $\left(\mathrm{NO}_{3}-\mathrm{N}\right)$, total phosphorus $(\mathrm{TP})$, calcium $(\mathrm{Ca})$, potassium $(\mathrm{K})$, magnesium $(\mathrm{Mg})$, total $\left(\mathrm{Al}_{\mathrm{t}}\right)$ and ionic $\left(\mathrm{Al}_{\mathrm{i}}\right)$ aluminium, mean temperature $\left(\mathrm{T}_{\mathrm{m}}\right)$, cumulative temperature $\left(\mathrm{T}_{\mathrm{c}}\right)$, temperature variation during a period $\left(\mathrm{T}_{\mathrm{v}}\right)$, and cumulative days $\left(\mathrm{D}_{\mathrm{c}}\right)$. The significant $(p<0.05)$ correlations are highlighted in bold.

\begin{tabular}{|c|c|c|c|c|c|c|c|}
\hline \multirow[t]{2}{*}{$Y$} & \multirow[t]{2}{*}{$X$} & \multicolumn{6}{|c|}{ Pearson $r$ between $Y$ and lagged $X$} \\
\hline & & $\mathrm{G}_{\mathrm{t}-2}$ & $\mathrm{~W}_{\mathrm{t}-1}$ & $\mathrm{~S}_{\mathrm{t}-1}$ & $\mathrm{G}_{\mathrm{t}-1}$ & $\mathrm{~W}_{\mathrm{t}}$ & $\mathrm{S}_{\mathrm{t}}$ \\
\hline \multirow[t]{13}{*}{ Adults } & $\mathrm{pH}$ & 0.3 & 0.7 & 0.7 & 0.7 & 0.3 & 0.3 \\
\hline & $\mathrm{NO}_{3}-\mathrm{N}$ & 0.3 & 0.2 & 0.3 & 0.2 & 0.2 & 0.0 \\
\hline & $\mathrm{TP}$ & 0.1 & 0.5 & 0.7 & 0.6 & 0.5 & 0.7 \\
\hline & $\mathrm{Ca}$ & 0.4 & 0.5 & 0.6 & 0.4 & 0.2 & 0.1 \\
\hline & K & 0.5 & 0.4 & 0.3 & 0.3 & 0.3 & 0.3 \\
\hline & $\mathrm{Mg}$ & 0.4 & 0.5 & 0.4 & 0.4 & 0.2 & 0.1 \\
\hline & $\mathrm{Al}_{\mathrm{t}}$ & -0.2 & -0.4 & 0.2 & 0.2 & 0.0 & 0.2 \\
\hline & $\mathrm{Al}_{\mathrm{i}}$ & -0.4 & -0.7 & -0.2 & -0.2 & -0.3 & -0.1 \\
\hline & $\mathrm{T}_{\mathrm{m}}$ & -0.2 & -0.3 & -0.2 & -0.3 & -0.2 & 0.3 \\
\hline & $\mathrm{T}_{\mathrm{c}}$ & -0.2 & -0.4 & -0.4 & 0.8 & -0.1 & 0.8 \\
\hline & $\mathrm{T}_{\mathrm{v}}$ & -0.3 & -0.3 & -0.3 & 0.1 & 0.1 & 0.9 \\
\hline & $\mathrm{D}_{\mathrm{c}}$ & 0.0 & -0.6 & -0.5 & 0.7 & 0.2 & 0.8 \\
\hline & & & & & $\mathrm{G}_{\mathrm{t}-1}$ & $\mathrm{~W}_{\mathrm{t}}$ & $\mathrm{S}_{\mathrm{t}}$ \\
\hline \multirow[t]{12}{*}{ Juveniles } & $\mathrm{pH}$ & & & & 0.1 & 0.2 & 0.0 \\
\hline & $\mathrm{NO}_{3}-\mathrm{N}$ & & & & 0.1 & 0.0 & 0.1 \\
\hline & $\mathrm{TP}$ & & & & -0.3 & -0.1 & 0.1 \\
\hline & $\mathrm{Ca}$ & & & & 0.2 & 0.2 & 0.3 \\
\hline & $\mathrm{K}$ & & & & 0.1 & 0.1 & 0.1 \\
\hline & $\mathrm{Mg}$ & & & & 0.2 & 0.2 & 0.0 \\
\hline & $\mathrm{Al}_{\mathrm{t}}$ & & & & -0.3 & -0.3 & 0.1 \\
\hline & $\mathrm{Al}_{\mathrm{i}}$ & & & & -0.2 & -0.3 & 0.0 \\
\hline & $\mathrm{T}_{\mathrm{m}}$ & & & & -0.4 & -0.5 & 0.2 \\
\hline & $\mathrm{T}_{\mathrm{c}}$ & & & & 0.2 & -0.6 & -0.3 \\
\hline & $\mathrm{T}_{\mathrm{v}}$ & & & & -0.3 & -0.7 & -0.2 \\
\hline & $\mathrm{D}_{\mathrm{c}}$ & & & & 0.3 & -0.6 & -0.5 \\
\hline
\end{tabular}


Table 2 Results of the factor analysis (FA) and partial least squares multiple regression (PLSR). Predictor $(X)$ variables lagged at age of the first winter $\left(\mathrm{W}_{\mathrm{t}-1}\right.$; for the period settings see methods and Fig. 2.) included $\mathrm{pH}$, nitrate $\left(\mathrm{NO}_{3}-\mathrm{N}\right)$, total phosphorus $(\mathrm{TP})$, calcium $(\mathrm{Ca})$, potassium $(\mathrm{K})$, magnesium $(\mathrm{Mg})$, ionic aluminium $\left(\mathrm{Al}_{\mathrm{i}}\right)$, and cumulative temperature $\left(\mathrm{T}_{\mathrm{c}}\right)$. Response $(Y)$ variable analysed in PLSR refers to the adult population growth. FA results: the factor (F1-3) loadings rotated in the manner of Varimax rotation; the variability $\left(\mathrm{R}^{2}\right.$ of $\left.X\right)$ explained by each factor; the communalities from three factors (Commun.). PLSR results: the weights (w) of three components (COMP 1-3) extracted; the explained variability of response $\left(R^{2}\right.$ of $\left.Y\right)$ and predictor $\left(R^{2}\right.$ of $\left.X\right)$ variables; the regression coefficients for the multiple linear regression models based on one (1C), two (2C) and three (3C) components. The significant ( $p$ $<0.05)$ correlations are highlighted in bold.

\begin{tabular}{|c|c|c|c|c|c|c|c|c|c|c|c|}
\hline \multicolumn{5}{|c|}{ FA } & \multicolumn{7}{|c|}{ PLSR } \\
\hline \multirow[b]{2}{*}{$X$} & \multicolumn{3}{|c|}{ Factor loadings } & \multirow[t]{2}{*}{ Commun. } & \multirow[b]{2}{*}{$X$} & \multirow{2}{*}{$\begin{array}{c}\mathrm{w} \\
\text { COMP1 }\end{array}$} & \multirow{2}{*}{$\begin{array}{c}\mathrm{w} \\
\text { COMP2 }\end{array}$} & \multirow{2}{*}{$\begin{array}{c}\mathrm{w} \\
\text { COMP3 }\end{array}$} & \multicolumn{3}{|c|}{ Regression coefficients } \\
\hline & F1 & F2 & F3 & & & & & & $1 \mathrm{C}$ & $2 \mathrm{C}$ & $3 \mathrm{C}$ \\
\hline$\overline{\mathrm{pH}}$ & 0.46 & 0.86 & -0.06 & 0.96 & $\overline{\mathrm{pH}}$ & 0.46 & 0.23 & -0.60 & 3583 & 4711 & -7352 \\
\hline $\mathrm{NO}_{3}-\mathrm{N}$ & 0.96 & -0.16 & 0.18 & 0.99 & $\mathrm{NO}_{3}-\mathrm{N}$ & 0.17 & -0.33 & -0.04 & 315 & -65.2 & -262 \\
\hline $\mathrm{TP}$ & 0.97 & 0.07 & 0.01 & 0.95 & $\mathrm{TP}$ & 0.34 & -0.09 & 0.22 & 182 & 152 & 455 \\
\hline $\mathrm{Ca}$ & 0.98 & 0.18 & 0.08 & 0.99 & $\mathrm{Ca}$ & 0.34 & -0.11 & 0.00 & 1492 & 1182 & 1143 \\
\hline K & 0.99 & 0.09 & 0.07 & 0.99 & K & 0.31 & -0.16 & -0.03 & 800 & 5402 & 339 \\
\hline $\mathrm{Mg}$ & 0.98 & 0.11 & 0.00 & 0.98 & $\mathrm{Mg}$ & 0.36 & -0.06 & 0.26 & 5624 & 5066 & 15576 \\
\hline $\mathrm{Al}_{\mathrm{i}}$ & 0.22 & -0.86 & 0.41 & 0.95 & $\mathrm{Al}_{\mathrm{i}}$ & -0.47 & -0.78 & -0.65 & -4.66 & -9.51 & -26.5 \\
\hline $\mathrm{T}_{\mathrm{c}}$ & 0.08 & -0.23 & 0.97 & 0.99 & $\mathrm{~T}_{\mathrm{c}}$ & -0.29 & -0.43 & 0.31 & -1.79 & -3.46 & 1.57 \\
\hline \multirow[t]{2}{*}{$\mathrm{R}^{2}$ of $X$} & 0.63 & 0.83 & 0.98 & & $\mathrm{R}^{2}$ of $X$ & 0.54 & 0.90 & 0.92 & & Intercepts & \\
\hline & & & & & $\mathrm{R}^{2}$ of $Y$ & 0.58 & 0.72 & 0.85 & -18559 & -19877 & 35565 \\
\hline
\end{tabular}



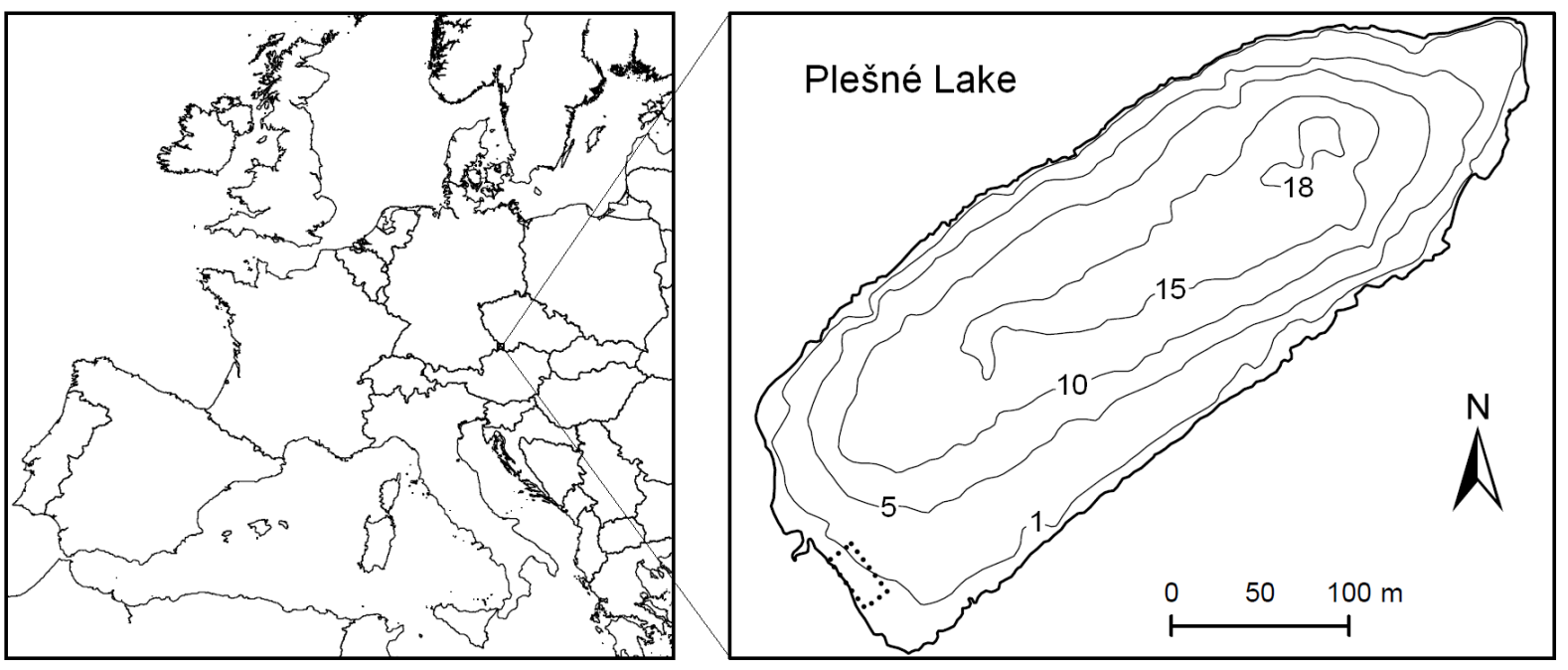

520

Fig. 1 Situation map of Plešné Lake and study plots (dotted rectangle) of Isoëtes echinospora 522 population along the south-west shore. 

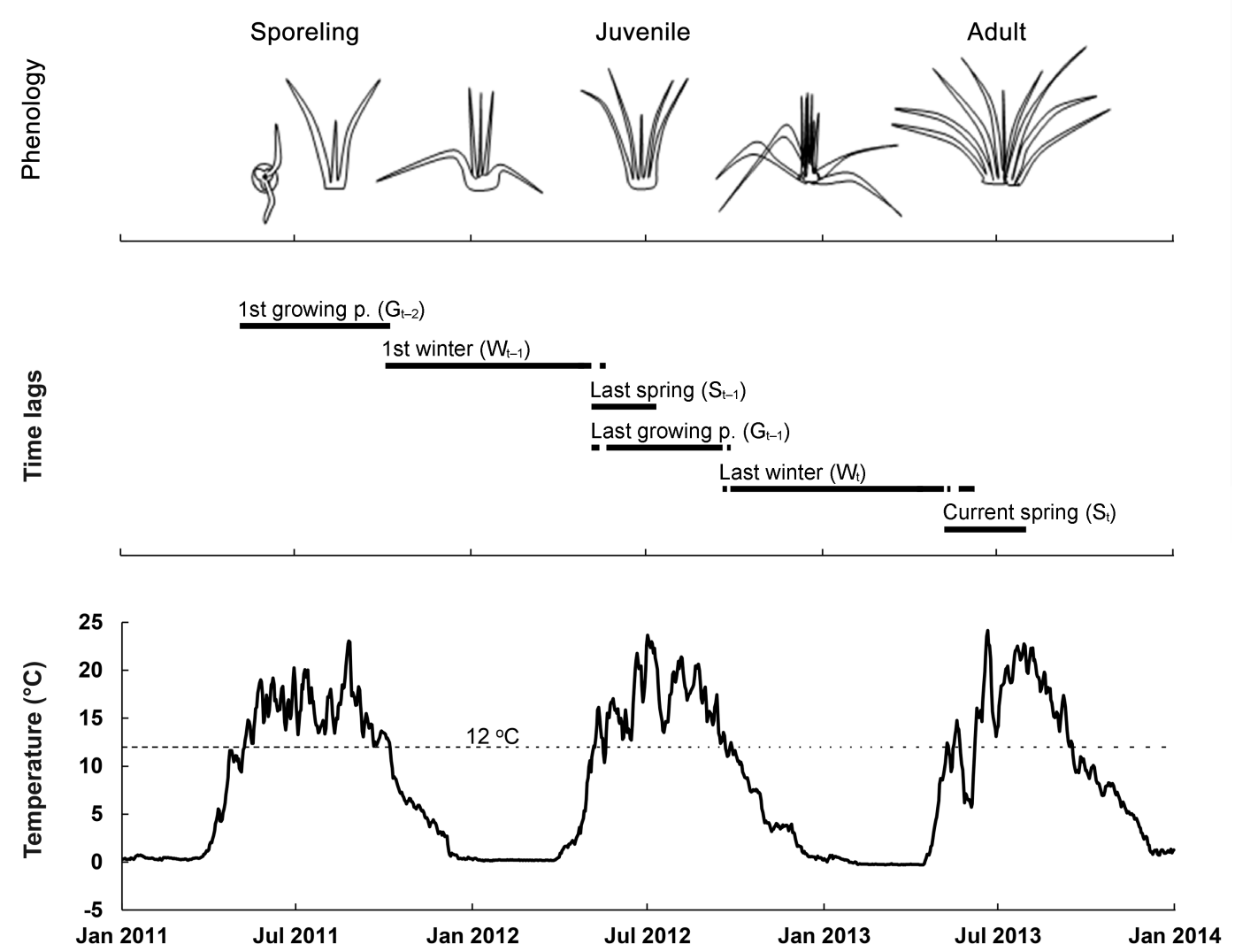

Fig.

5242 Illustration of Isoëtes echinospora phenology related to time lags of lake water effects. The time lags are based on lake water temperature in Plešné Lake and the species specific temperature threshold $\left(12^{\circ} \mathrm{C}\right)$ for germination. The periods below and above the threshold are winter (W) and growing (G) periods, respectively. The spring (S) period includes both the next 60 days when daily mean temperature rises above the threshold and all intermittent colder days if present. Lake water conditions are lagged by up to two years $(t, t-1, t-2)$ of plant early ontogeny. 



Fig. 3 Trends in daily mean water temperature and water chemistry in Plešné Lake during 1990-2014: a) lake water temperature recorded at the quillwort plant level with the Minikin QT sensor in 2003-2014 and reconstructed with model CE-QUAL-W2 in 1998-2003 (calibration period 2004-2013), b) pH and concentrations of total phosphorus (TP), c) total

$537\left(\mathrm{Al}_{\mathrm{t}}\right)$ and ionic $\left(\mathrm{Al}_{\mathrm{i}}\right)$ aluminium, d) calcium $(\mathrm{Ca})$, potassium $(\mathrm{K})$ and magnesium $(\mathrm{Mg})$ cations, 538 e) sulphate $\left(\mathrm{SO}_{4}{ }^{2-}\right)$ and nitrate $\left(\mathrm{NO}_{3}-\mathrm{N}\right)$. 
(a)

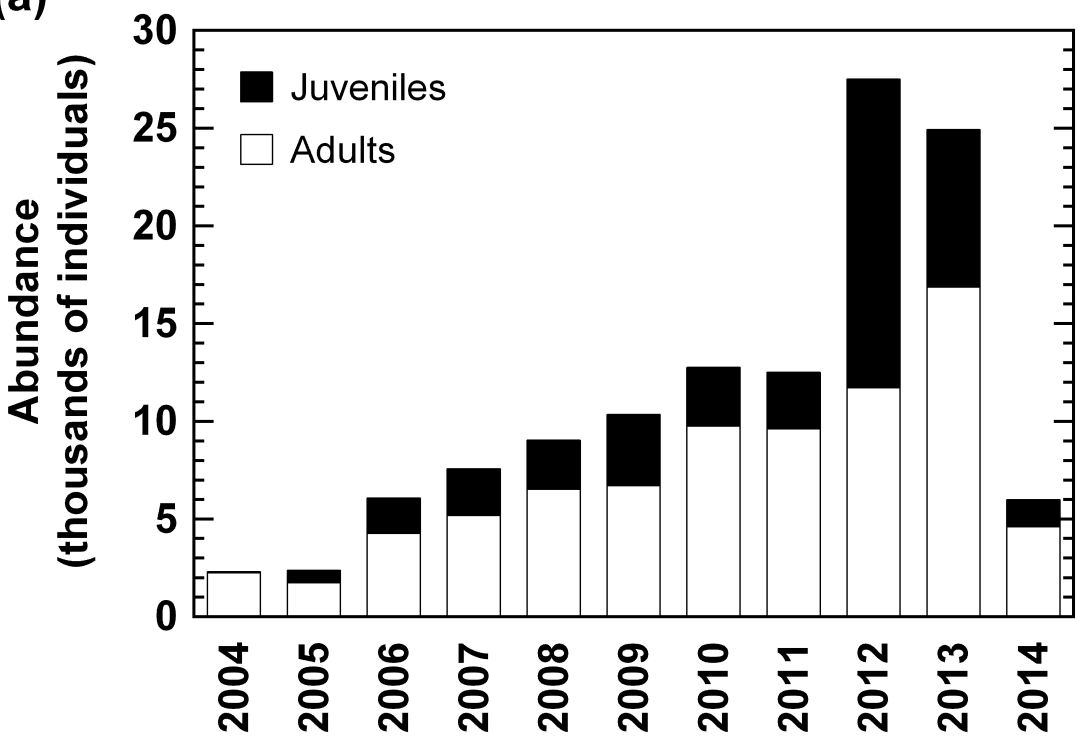

(b)

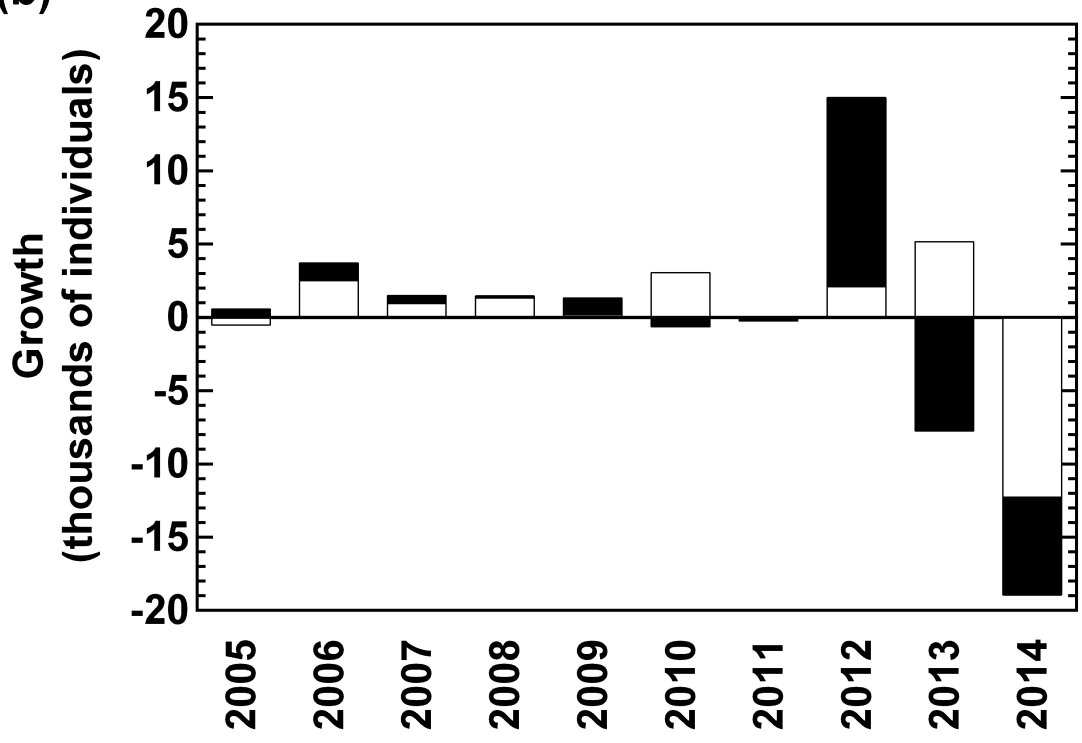

540 Fig. 4 Plant abundance (a) and population growth (b) of Isoëtes echinospora in Plešné Lake 541 between 2004 and 2014. Growth of the adult or juvenile population is defined as a year-to542 year change in an appropriate plant abundance observed in July. 

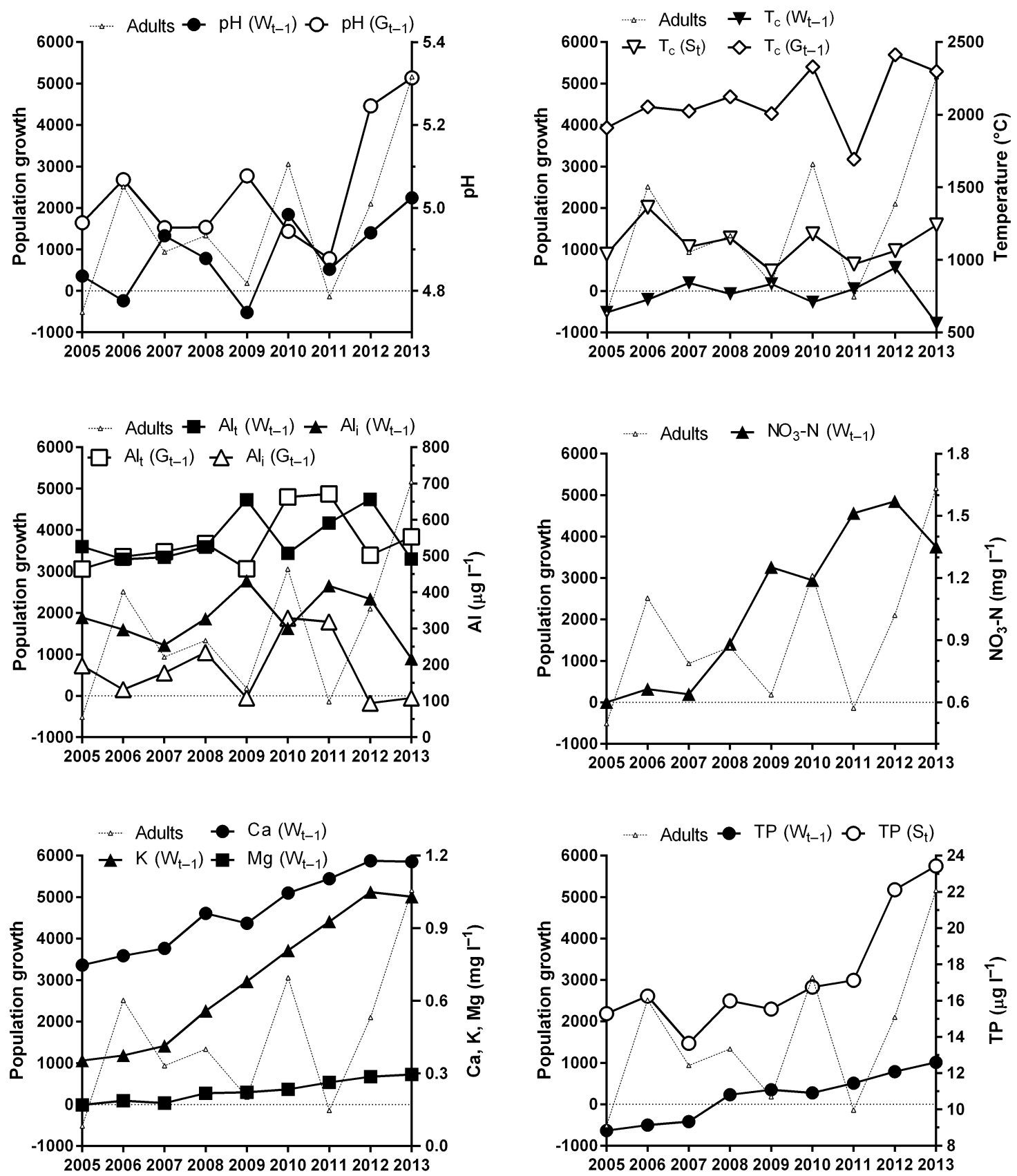

544 Fig. 5 Population growth of Isoëtes echinospora in Plešné Lake plotted with lake water characteristics that are lagged at distinct periods. The growth is defined as a year-to-year change in number of adult plants observed in July. Mean values of $\mathrm{pH}$, nitrate $\left(\mathrm{NO}_{3}-\mathrm{N}\right)$, total phosphorus $(\mathrm{TP})$, calcium $(\mathrm{Ca})$, potassium $(\mathrm{K})$, magnesium $(\mathrm{Mg})$, total $\left(\mathrm{Al}_{\mathrm{t}}\right)$ and ionic $\left(\mathrm{Al}_{\mathrm{i}}\right)$ aluminium, and cumulative temperature $\left(T_{c}\right)$ in spring $(S)$, growing $(G)$, or winter $(W)$ periods were lagged by up to one year $(t, t-1)$. For the period settings and the respective phenophases see methods and Fig. 2. 


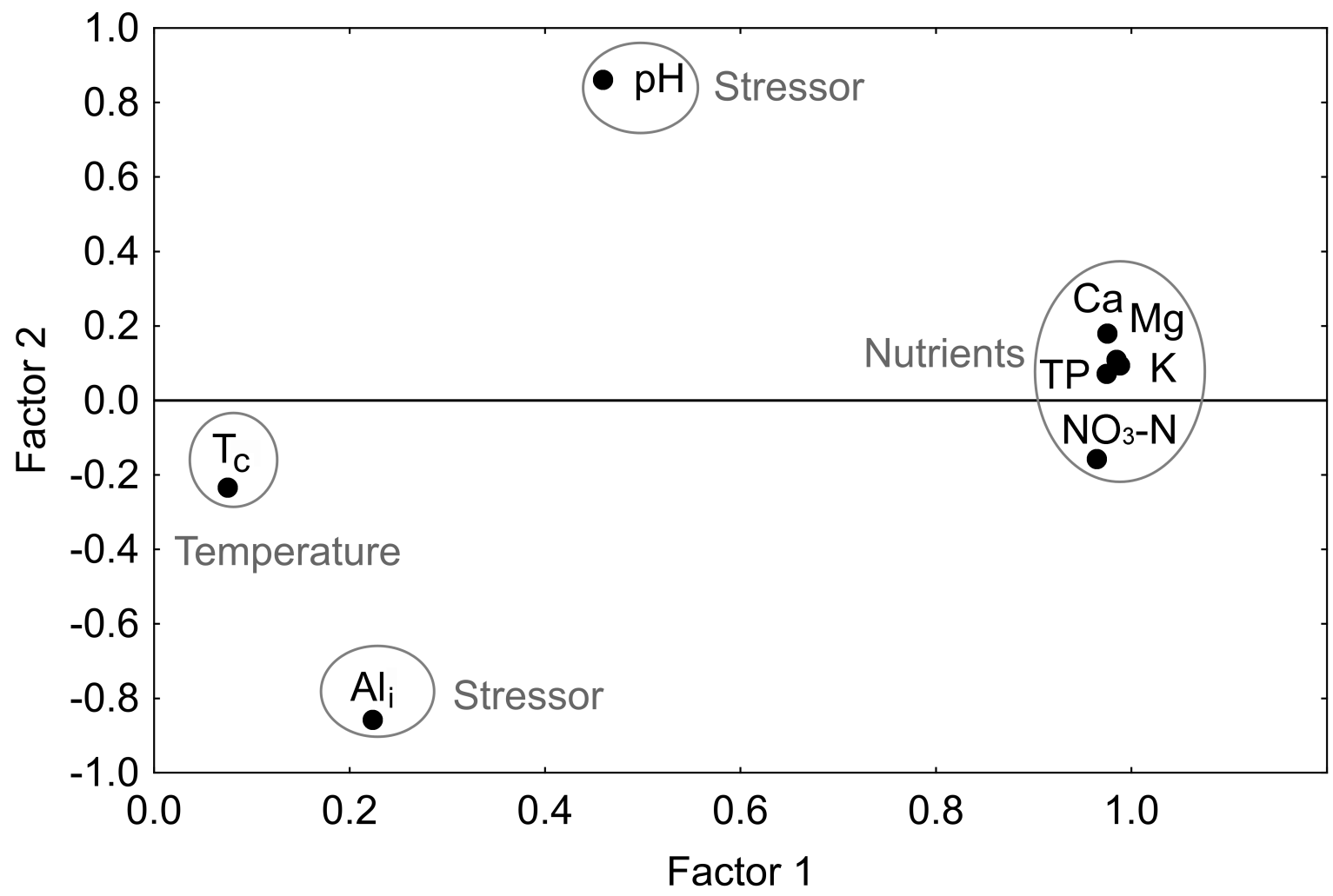

552 Fig. 6 Results of factor analysis - 2D scatterplot of factor loadings rotated in the manner of 553 Varimax rotation. Mean values of $\mathrm{pH}$, nitrate $\left(\mathrm{NO}_{3}-\mathrm{N}\right)$, total phosphorus (TP), calcium $(\mathrm{Ca})$, 554 potassium $(\mathrm{K})$, magnesium $(\mathrm{Mg})$, ionic aluminium $\left(\mathrm{Al}_{\mathrm{i}}\right)$, and cumulative temperature $\left(\mathrm{T}_{\mathrm{c}}\right)$ of 555 Plešné Lake water lagged at age of the first wintering $\left(\mathrm{W}_{\mathrm{t}-1}\right)$ were analysed. The three factors 556 extracted were intrepreted as nutrients (Factor 1), stressors (Factor 2) and temperature (Factor 557 3; axis not shown). The summary of factor loadings and communalities is shown in Table 2. 

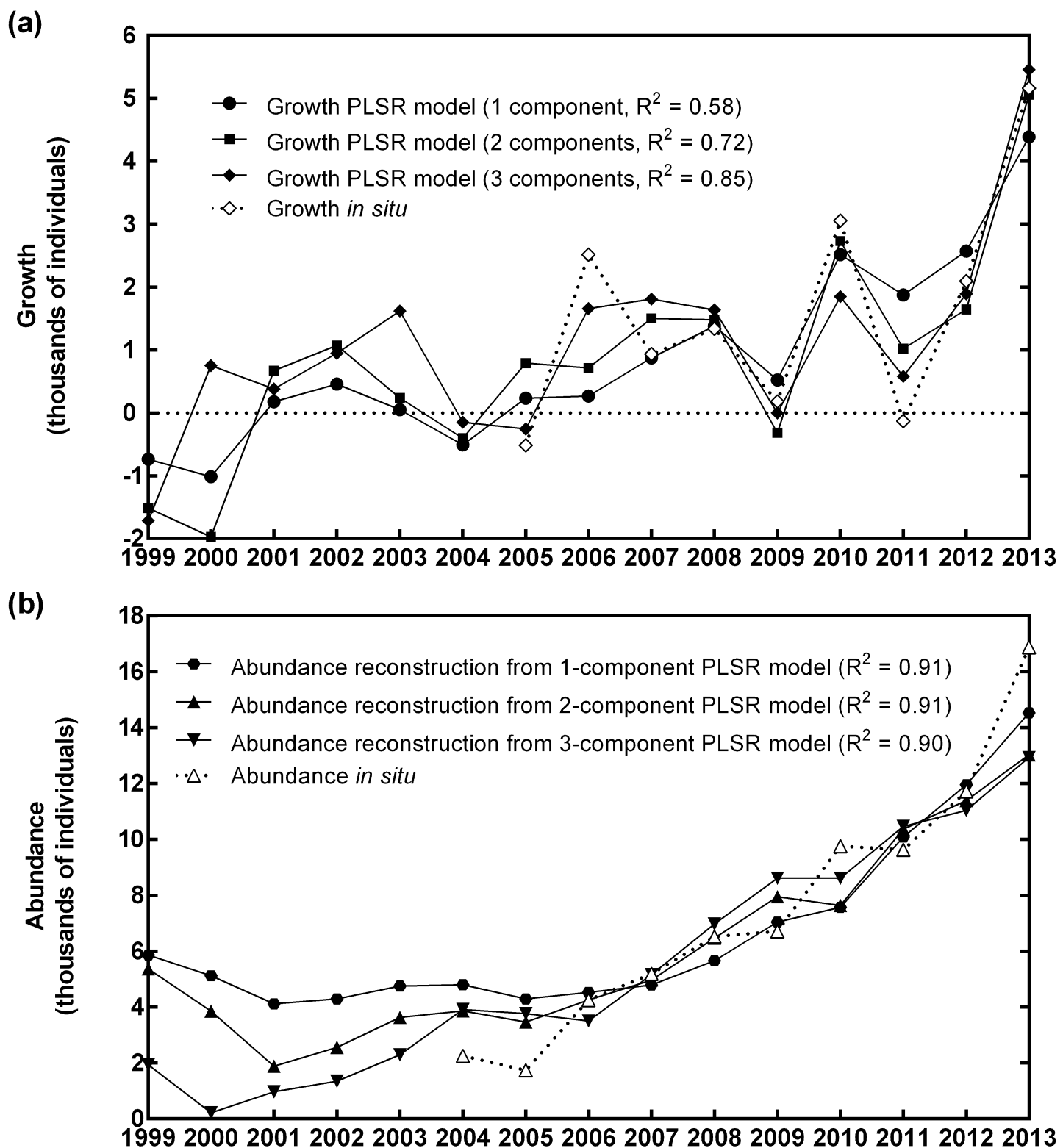

559 Fig. 7 Population growth (a) and abundance (b) of Isoëtes echinospora in Plešné Lake observed between 2005 and 2013 and reconstructed by the Partial least squares regression (PLSR) model from 1999 to 2013. Annual growth is year-to-year change in number of adult plants (abundance) observed in July. The weights of the original predictor variables and the 

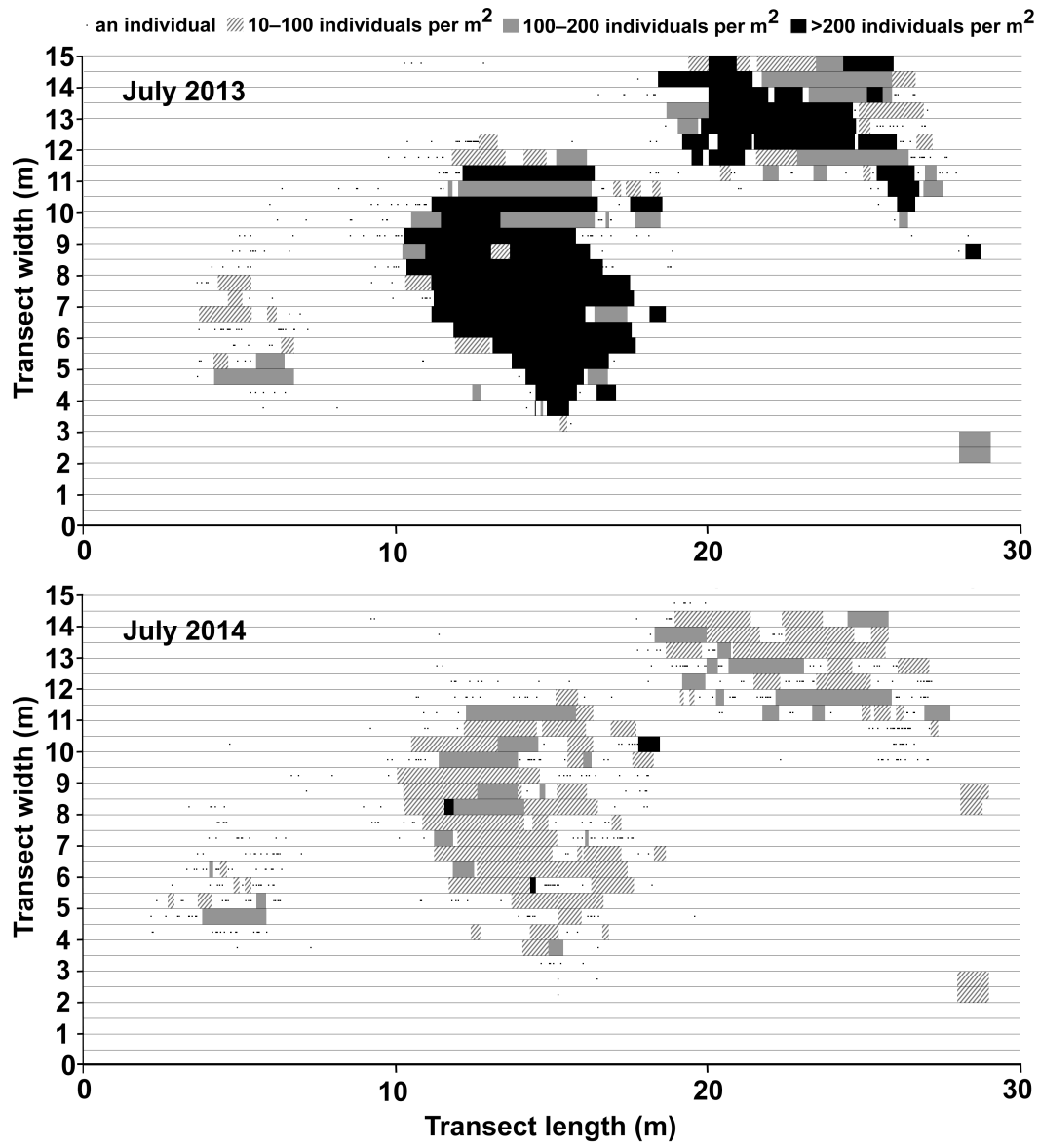

565 Fig. 8 Abundance of the adult population of Isoëtes echinospora in Plešné Lake before and 566 after its grazing in October 2013. Underwater visual censuses of adult plants were performed 567 in transitory strip transects $(0.5 \times 10 \mathrm{~m})$ at 3 adjacent study plots $(10 \times 15 \mathrm{~m})$ covering whole 568 lake population in July 2013 and 2014. Transect length refer to cumulative length of three 569 adjacent transects within the study plots. 